\title{
New chronological and stratigraphical data on the Ivrea amphitheatre (Piedmont, NW Italy)
}

\author{
Franco Gianotti $^{\mathrm{a}, *}$, Maria Gabriella Forno ${ }^{\mathrm{a}}$, Susan Ivy-Ochs ${ }^{\mathrm{b}, \mathrm{c}}$, Peter W. Kubik ${ }^{\mathrm{d}}$ \\ ${ }^{a}$ Dipartimento di Scienze della Terra, Università di Torino, via Valperga di Caluso 35, 10125 Torino, Italy \\ ${ }^{\mathrm{b}}$ Institut für Teilchenphysik, ETH Hönggerberg, CH-8093 Zürich, Switzerland \\ ${ }^{\mathrm{c}}$ Geographisches Insitut, Universität Zürich-Irchel, CH-8057 Zürich, Switzerland \\ ${ }^{\mathrm{d}}$ Paul Scherrer Insitut c/o Institut für Teilchenphysik, ETH Hönggerberg, CH-8093 Zürich, Switzerland
}

Available online 8 March 2008

\begin{abstract}
The Ivrea amphitheatre (IA) in NW Italy has been studied since 1850, on pedostratigraphic and morphological bases. Three stratigraphic groups of glacial sediments were distinguished. Newly recognized stratigraphic boundaries are based on interstadial/ interglacial units, palaeosols and lacustrine organic layers interbedded with glacigenic deposits, and on pedostratigraphy. Mapping of morphological features and associated marginal and sub-glacial deposit facies was used to characterize and reconstruct glacial margin fluctuations. Based on the field evidence, the stratigraphical limits recognized at single sites can be interpolated over the whole amphitheatre. Ten stratigraphic units (referred to as alloformations: Afs) were distinguished and mapped. They are related to at least as many glacial episodes ranging in age from the end of the Early Pleistocene to the Late Pleistocene. The youngest three glacial units (Serra Af, Piverone Af and Ivrea Af) and one interstadial level (Alice Superiore Unit between Serra and Piverone Afs) are discussed in detail. Based on biostratigraphical and pedological, as well as sedimentological and morphological data, the Serra Af can be attributed to MIS 6 and Piverone Af to MIS 4. The ${ }^{10} \mathrm{Be}$ surface exposure ages from two boulders $(27.9 \pm 3.1,32.4 \pm 4.0 \mathrm{kyr})$ on the Serra d'Ivrea moraine provide only a minimum age for moraine construction. The alignment of typical ice marginal landforms (moraines and kame terraces) for the more recent unit (Ivrea Af) has allowed recognition of 12 principal stadials during the LGM and Lateglacial; 6 stadials in the amphitheatre and 6 stadials in Dora Baltea Valley, and reconstruction of the nature of the last glacial retreat from the amphitheatre to the cirques. ${ }^{10} \mathrm{Be}$ exposure ages from three boulders related to Ivrea Af are $13.1 \pm 1.0,17.4 \pm 2.6$ and $20.8 \pm 1.5 \mathrm{ka}$. The latter two ages indicate that the Dora Baltea Glacier deposited the Ivrea Af in the IA during MIS 2. The ${ }^{10}$ Be exposure ages of $14.6 \pm 1.2$ and $14.0 \pm 0.9 \mathrm{ka}$ from a polished bedrock surface some $15 \mathrm{~km}$ upstream from the amphitheatre provide a minimum age for ice decay. (C) 2008 Elsevier Ltd and INQUA. All rights reserved.
\end{abstract}

\section{Introduction}

The Ivrea amphitheatre (IA) is the main evidence of Quaternary glaciations in the Dora Baltea basin (NW Italy). It is one of the biggest $\left(505 \mathrm{~km}^{2}\right)$ Italian morainic amphitheatres, although smaller than the Garda and Verbano amphitheatres. Its terminal moraines are about $120 \mathrm{~km}$ from the present margins of the Monte Bianco glaciers (Fig. 1). The amphitheatre is characterized by a wide flat internal depression $\left(200 \mathrm{~km}^{2}\right.$ at an elevation of $250-215 \mathrm{~m}$ asl) which is encircled by a high moraine

\footnotetext{
*Corresponding author. Tel./fax: + 39165767825 .

E-mail addresses: franco.gianotti@alice.it (F. Gianotti), gabriella.forno@unito.it (M.G. Forno), ivy@phys.ethz.ch (S. Ivy-Ochs).
}

complex with a relief difference reaching $700 \mathrm{~m}$. The IA contains two morphological jewels: the Serra d'Ivrea lateral moraine is the topographically highest expression of glacial sedimentation, while the Colli d'Ivrea (Ivrea Hills) area exhibits abundant evidence of sub-glacial erosional processes (Fig. 2). The amphitheatre was constructed during all the interglacial-glacial cycles of the second half of the Quaternary. The most distal moraine has been attributed to the Early Pleistocene (Carraro et al., 1991), while the most proximal end moraine arc was referred to the Last Glacial Maximum (LGM) (based on ${ }^{14} \mathrm{C}$ dating by Schneider (1978) and Arobba et al. (1997)). The aim of the present work is to describe the stratigraphy of the most recent units, related to the upper part of Middle Pleistocene and the Late Pleistocene, comprising the Serra d'Ivrea and 


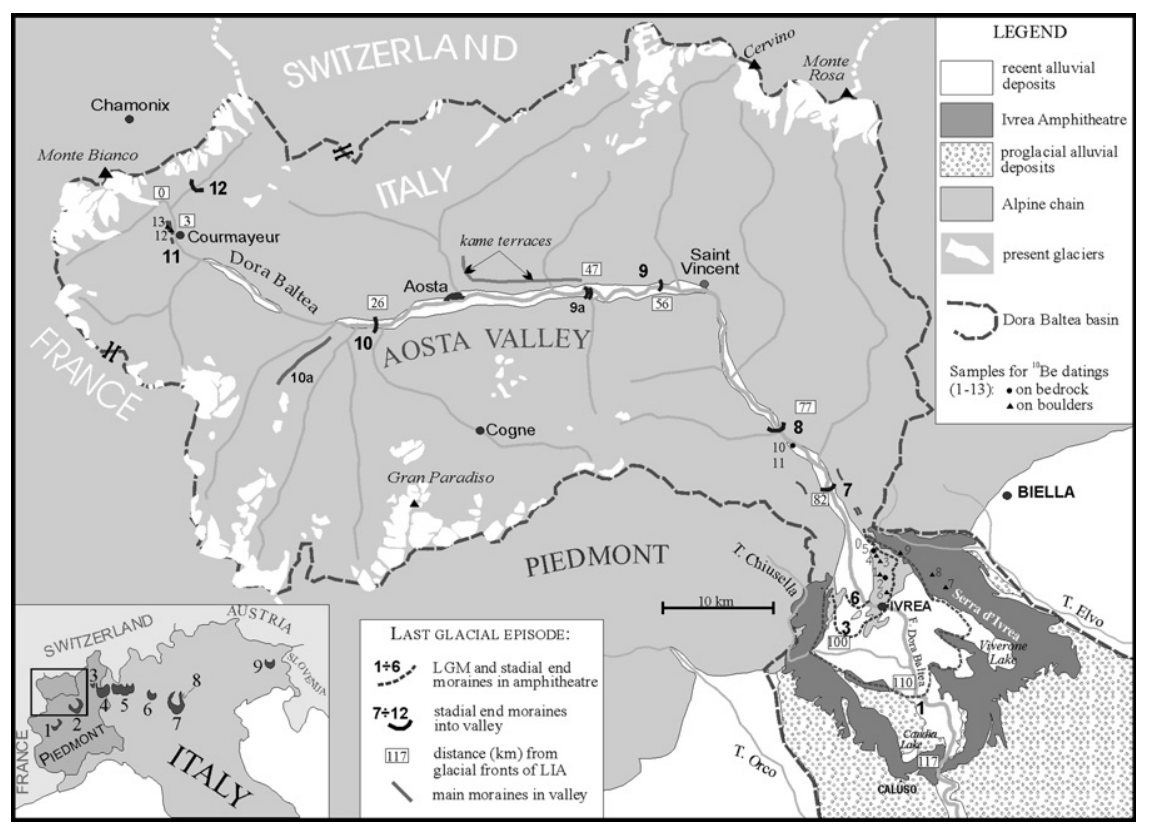

Fig. 1. Geomorphological sketch map of the Dora Baltea basin, with the mountain basin (corresponding to Valle d'Aosta region) of nearly $3400 \mathrm{~km}^{2}$ and the IA at the outlet of the valley. LGM-Lateglacial stadials in Colli d'Ivrea area and into the valley are shown (modified from Gianotti, 2007): Andrate (1), Quintas (2, not represented), Pavone (3), Bienca (4, not represented), Prà San Pietro (5, not represented), Germano (6), Torredaniele (7), Bard (8), Chambave (9), Saint Pierre (10), Courmayeur (11) and Planpinceux (12). Main morainic amphitheatres of Italian Alps: Rivoli-Avigliana (Susa Valley; 1), Ivrea (Dora Baltea Valley; 2), Orta (Strona Valley; 3), Verbano (Ossola + Ticino valleys; 4), Lario (Valtellina and Como Lake; 5), Iseo (Camonica Valley; 6), Garda (Adige-Sarca valleys; 7), Rivoli Veronese (“Lagarina” Valley; 8), Tagliamento (Tagliamento Valley; 9).

Piccola Serra moraines (Fig. 3). New data have been acquired from field relationships based on facies analysis and pedostratigraphy, as well as surface exposure dating with cosmogenic ${ }^{10} \mathrm{Be}$.

\section{Regional setting}

The IA is located in the Piedmont region at the outlet of the Dora Baltea Valley, between the internal margin of the Western Alps and the Po Plain (Fig. 1). The imposing morphological evidence of the IA is a consequence of the elevated topography and proximity of the plain to its mountain catchment area. The Dora Baltea Valley is a wide $\left(3400 \mathrm{~km}^{2}\right)$ and branched valley system with more than 30 main tributary valleys, bounded by some of the highest "4000" peaks of the European Alps (Monte Bianco, Monte Rosa, Cervino and Gran Paradiso), which are only a short distance from the Po Plain. This basin for the most part coincides with the Aosta Valley Region. It is the only valley to cut all the main structural systems (from the Sudalpine to the Helvetic System) that form the Alpine range. The lithologic composition of the basin is reflected in the petrographic variety of the glacigenic deposits found in the IA, dominated by metamorphic silicate rocks and subordinate calcareous clasts. Austroalpine eclogitic micaschist and gneiss with eclogite and glaucophanite are prevalent. There is an abundance of serpentinite, amphibolite, prasinite, metagabbro, quartzite, calcschist, and marble from the Piemontese Zone. Diorite and mafic granulite from the Sudalpine System and many other types of orthogneiss and granitoids, paragneiss and micaschist from all the continental systems are also represented.

The IA (Figs. 4 and 5) lies on metamorphic basement comprised of Ercinian (Paleozoic) and Alpine (CretaceousOligocene) rocks, as well as a marine, transitional and alluvial sequence of Early Pliocene-Early Pleistocene age. The bedrock is comprised of Austroalpine eclogitic micaschists (Sesia-Lanzo Zone), forming raised alpine relief to the NW, and of Sudalpine basement with Ercinian metamorphism (Canavese Zone low grade schist with granitic and dioritic intrusions; Ivrea-Verbano Zone high grade mafic granulite) to the SE, forming the low Colli d'Ivrea reliefs. The two systems meet along the SW-NE trending External Canavese Line (ECL in Fig. 4). A second subparallel fault (the Internal Canavese Line; ICL in Fig. 4) brings the deep Ivrea-Verbano Zone continental crust into contact with the Canavese Zone shallow continental crust (Biino and Compagnoni, 1989). The Colli d'Ivrea represent Sudalpine basement outcropping over a wide area $\left(21 \mathrm{~km}^{2}\right)$ in the internal depression of the amphitheatre (Fig. 4). They are a group of hills of low rounded relief, formed by sub-glacial erosion of the IvreaVerbano Zone mafic granulite (Forno et al., 2005a,b). These hills represent the threshold of a glacial excavation hollow, the last of a sequence into the Dora Baltea Valley (Fig. 9), extending below sea level (at least $-20 \mathrm{~m}$ ), cut by the Dora Baltea glacier into the fractured rocks of the Canavese Zone. 


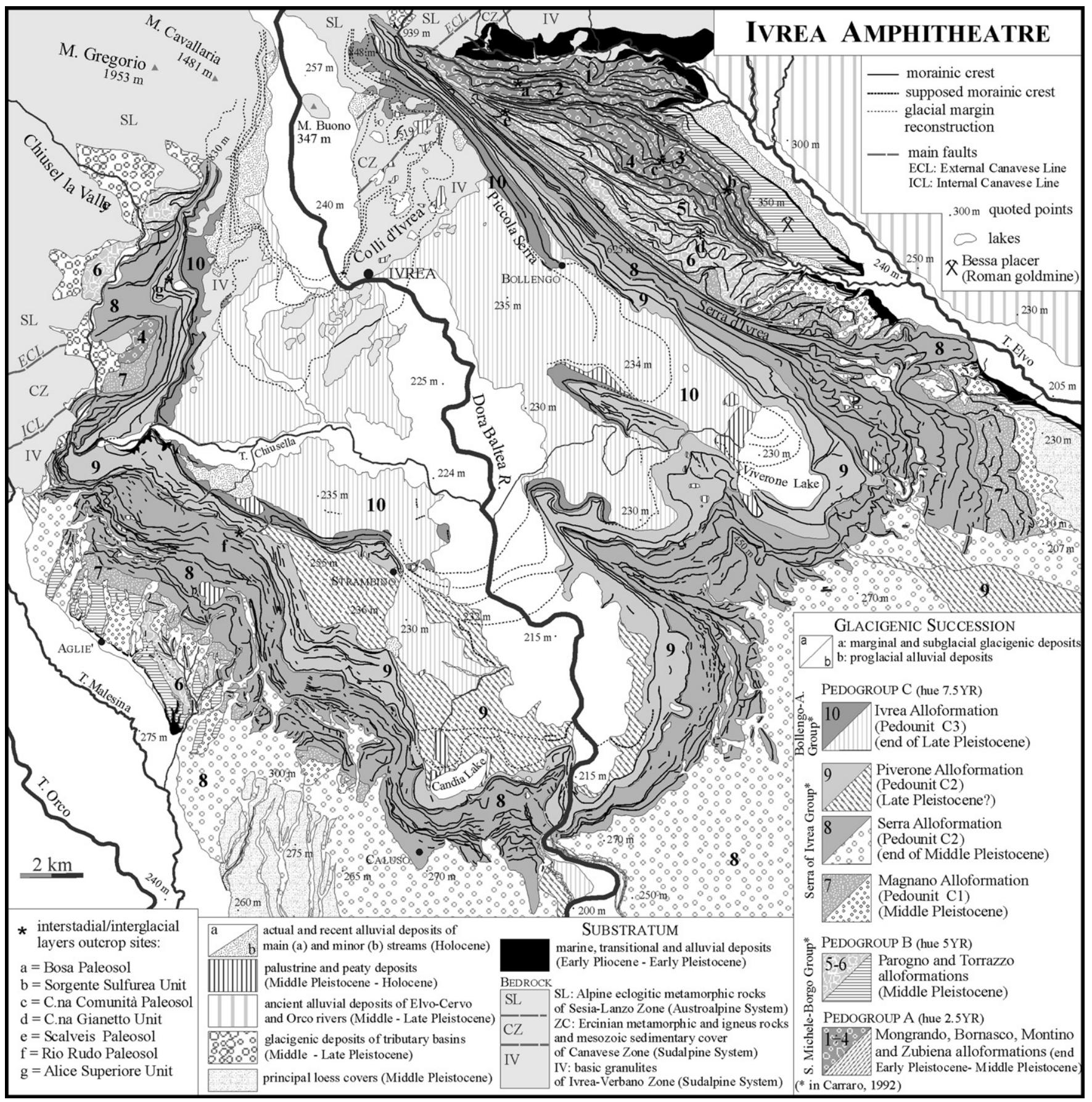

Fig. 2. Geologic map of the Ivrea Amphitheatre. Pedostratigraphic groups are indicated and further subdivided into ten alloformations based on the presence of interbedded interstadial or interglacial markers or by pedostratigraphy (modified from Gianotti, 2007).

\section{Historical background}

Studer (1844) first recognized the glacial nature of Serra d'Ivrea, the main moraine of the amphitheatre. The entire IA was described by Martins and Gastaldi (1850). In the first surveys by Gastaldi and Bruno (Bruno, 1877), incorporated in the 1:400,000 Western Alps Map (1908), the IA was regarded as an undifferentiated landform constructed during only a single glaciation. The glacial deposits ("deposito morenico") were distinguished from Pliocene sediments, outwash sediments ("diluvium") and postglacial fluvial sediments. Baretti (1877) and Sacco (1888) also supported the single glaciation model.

Subsequently, Penck et al. (1894) and Penck and Brückner (1909) distinguished two alpine glaciations (Riss and Würm) of their classical stratigraphy and considered the Serra d'Ivrea to be the largest morainic ridge in the Alps. The model of numerous glaciations was used in the 


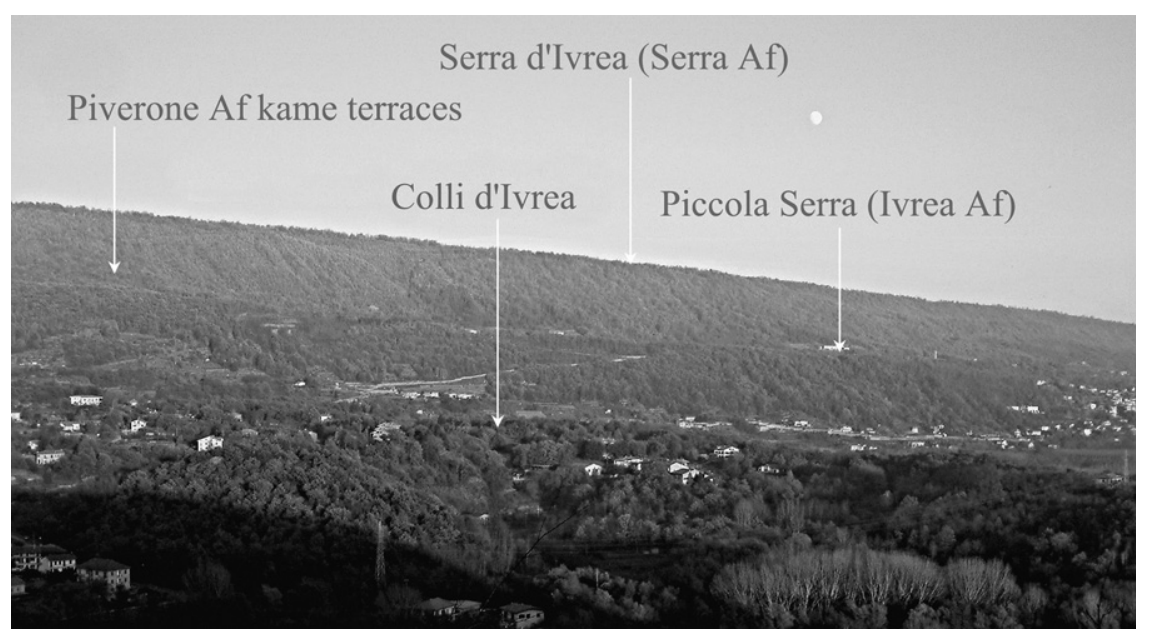

Fig. 3. Serra d'Ivrea (main moraine of Serra Alloformation) and Piccola Serra (main moraine of Ivrea Alloformation) in the left internal lateral sector of the amphitheatre.

first edition of Map-Sheet 42 "Ivrea" (Franchi et al., 1912) and sheet 43 "Biella" (Franchi and Stella, 1933) of the Geological Map of Italy (1:100,000 scale). The proximal moraines in the Serra d'Ivrea were named "morene würmiane, postwürmiane e recenti" and the more distal moraines were designated "morene antiche (prewürmiane)". Sacco (1927) distinguished three glaciations, tentatively correlated with Penck and Brückner's (1909) Mindel, Riss and Würm glaciations, but with different limits. Sacco (1927) considered Serra d'Ivrea as a Rissian moraine. The Sacco subdivisions were followed in the second edition of the 1:100,000 sheet 43 "Biella" (Bortolami et al., 1966) and in some synthesis publications (Carraro and Petrucci, 1969; Carraro et al., 1975).

Recently, on pedostratigraphic and morphologic grounds, the deposits were subdivided into three main groups (Carraro et al., 1991; Carraro, 1992). The San Michele-Borgo Group includes the ancient very weathered sediments preserved in the external areas of the left side of the IA. The Serra d'Ivrea Group includes most of lateral and frontal morainic ridges. The Bollengo-Albiano Group corresponds to relics of the more proximal morainic ridge, referred to the LGM.

The chronology of AMI is supported by a few, but significant, dates. In the left lateral sector of the distal morainic ridge, corresponding to the more ancient preserved ridge of the San Michele-Borgo Group, palaeomagnetic analysis of two lacustrine assemblages has been completed. The lower and upper sediments are separated by till, and show reverse and normal polarity, respectively. This sequence is assigned to the Early Pleistocene-Middle Pleistocene boundary (Carraro et al., 1991). In the right lateral sector a borehole in the intermorainic Alice Superiore Lake crosses a peaty body (Arobba et al., 1997) separating the Serra d'Ivrea and Bollengo-Albiano groups. Based on radiometric $\left(>43.000{ }^{14} \mathrm{C} \mathrm{BP}\right)$ and palynological (presence of Fagus) data, the Serra d'Ivrea Group was assigned to the Late Pleistocene. Dates on lateglacial peaty sediments in the Alice Superiore Lake $\left(14,200 \pm 150{ }^{14} \mathrm{C}\right.$ BP; Schneider, 1978) and in Villa Lake, in the lower Aosta Valley $\left(12,700 \pm 130{ }^{14} \mathrm{C} \mathrm{BP}\right.$; Brugiapaglia, 2001), supplied minimum ages of local deglaciation.

\section{Methods}

Morphological analysis based on photointerpretation and field surveying was made throughout the IA in order to reconstruct the alignments of ice-marginal landforms as moraines and kame terraces, which reflect the various halts of the glacial margin. Detailed field investigations were carried out at the scale of 1:5000 using the allostratigraphic method (North American Commission on Stratigraphic Nomenclature, 1983). Investigations were especially focussed on sites with excellent outcrops formed by stream incision. Based on these investigations, important discontinuities were identified as defined by marker units such as buried soils (paleosols sensu Cremaschi, 1987) or embedded palustrine levels, which represent interglacial or interstadial episodes. This allowed subdivision of the glacigenic succession into alloformations (Af) of climatostratigraphic significance, corresponding to distinct glacial episodes (Bini, 1997). The most recent alloformation was further subdivided on morphostratigraphical basis into allomembers, which are glacial stadials of the last glaciation (LGM and Lateglacial). Facies analysis followed the INQUA Classification (Goldthwait and Matsch, 1988), that distinguishes glacial deposits by position in relation to the glacier (marginal, subglacial, supraglacial and proglacial), by sedimentary process (melt-out, flow, lodgement, deformation, etc.) and by environment (aquatic or not aquatic).

Pedostratigraphy has been utilized both as a check of the validity of this reconstruction and as a tool for stratigraphical subdivision itself. Surficial soils and derived colluvium were considered. The colour of soils and weathered horizons was evaluated with the Munsell Soil Colour Chart. 


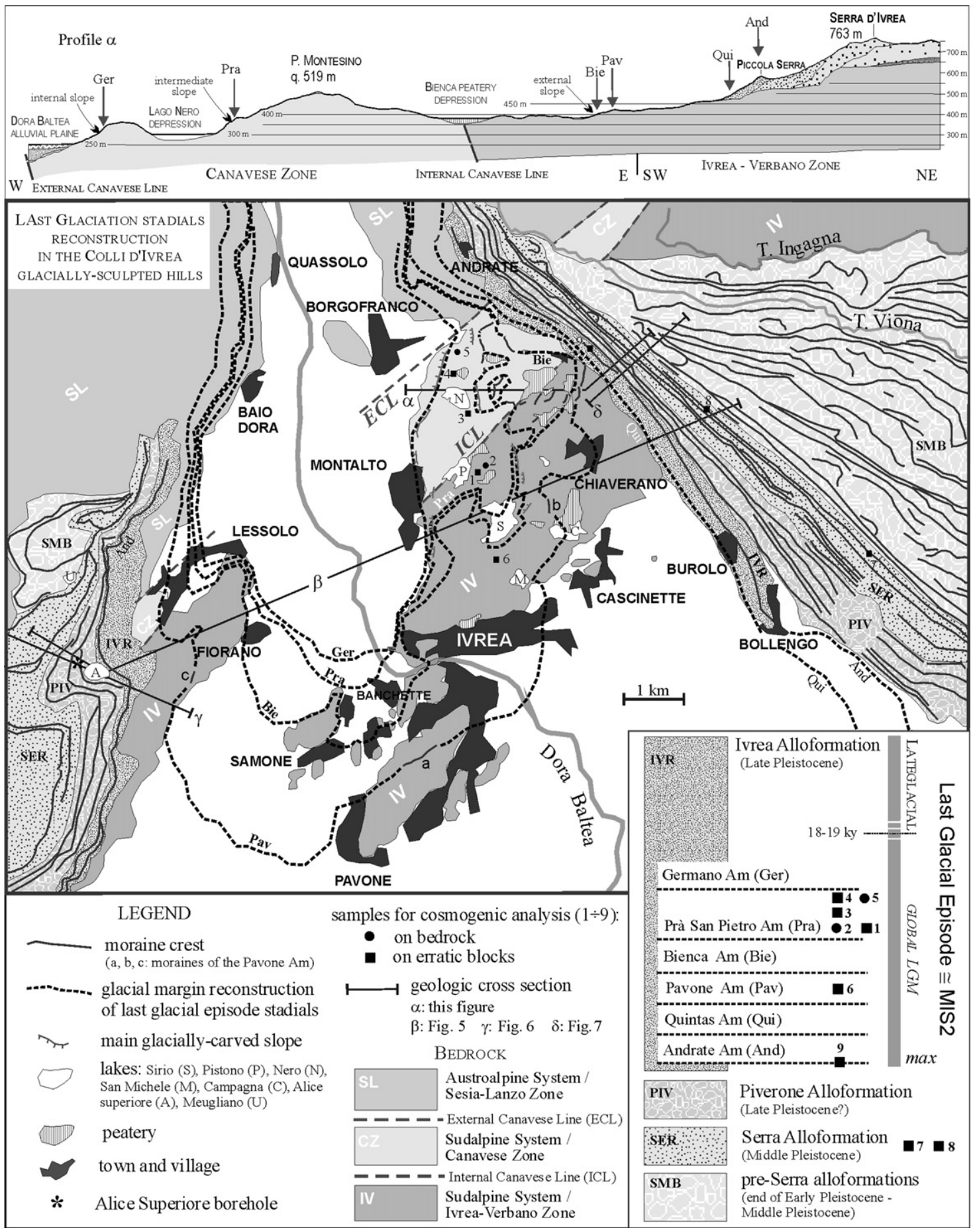

Fig. 4. Geologic map of the proximal internal sector of the Ivrea Amphitheatre. Locations of samples for exposure dating with ${ }^{10}$ Be are indicated. Erratics and glacially abraded bedrock surfaces from the Colli d'Ivrea area and boulders from the Piccola Serra and Serra d'Ivrea moraines were sampled.

Cosmogenic ${ }^{10} \mathrm{Be}$ was measured on samples taken from erratic blocks and glacially sculpted bedrock surfaces. Thirteen rock surfaces of boulders on the Serra Af moraines and Ivrea Af moraines (Piccola Serra), erratics and roches moutonnées in Colli d'Ivrea and Aosta Valley were sampled with hammer and chisel (Figs. 1 and 4). Seven analyses have been completed (Table 1). Samples for ${ }^{10} \mathrm{Be}$ measurement were prepared using standard procedures (Kohl and Nishiizumi, 1992; Ivy-Ochs, 1996; Ochs and Ivy-Ochs, 1997). ${ }^{10} \mathrm{Be} /{ }^{9} \mathrm{Be}$ along with appropriate standards and blanks were measured by accelerator mass spectrometry at the ETH/PSI tandem facility in Zurich (Synal et al., 1997). Exposure ages (Table 1) were calculated using a sea level, high latitude ${ }^{10} \mathrm{Be}$ production rate of $5.1 \pm 0.3$ atoms per gram $\mathrm{SiO}_{2}$ per year, with a contribution due to muons 


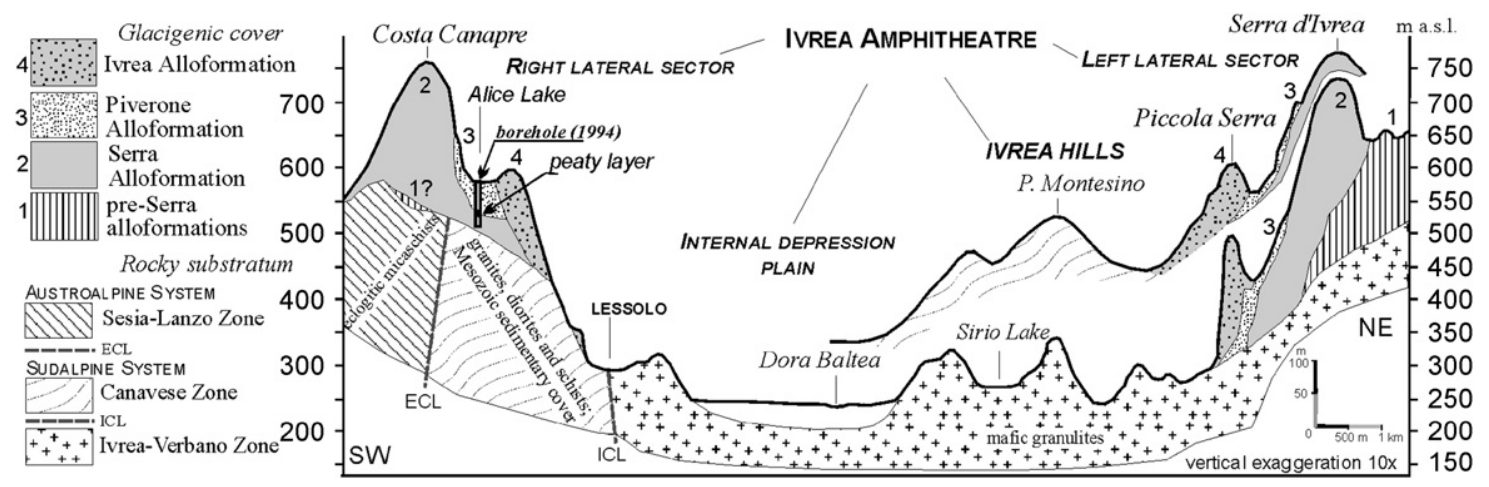

Fig. 5. Cross-section of the Ivrea Amphitheatre. Profile trace is shown in Fig. 4.

Table 1

Sample information (description, sample thickness and surrounding topography corrections), AMS-measured ${ }^{10}$ Be concentrations and calculated exposure ages

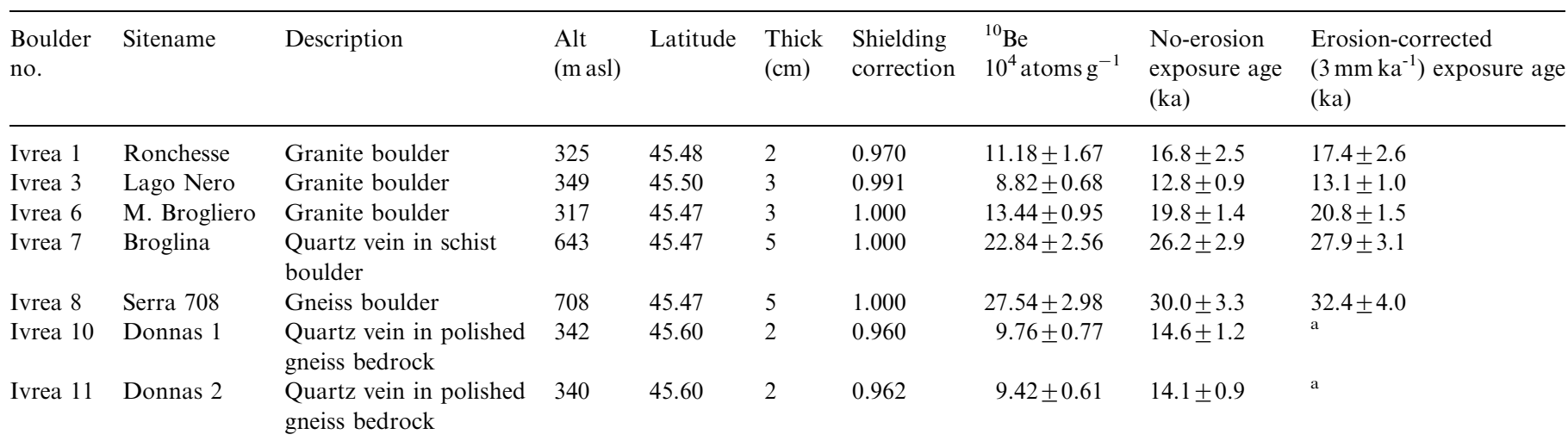

AMS measurement errors are at the $1 \sigma$ level, including the statistical (counting) error and the error due to the normalization to the standards and blanks. Age errors reflect analytical uncertainties only.

${ }^{a}$ Donnas 1 and 2 are from a polished surface and were not corrected for erosion.

of $2.2 \%$ (Stone, 2000). Scaling to the sample latitude (geographic) and altitude were also done, following Stone (2000). Shielding corrections followed Dunne et al. (1999). Except for Donnas 1 and 2 (Ivrea 10 and 11) which come from a glacially polished surface, exposure ages have also been calculated with a correction for rock surface weathering at a rate of $3 \mathrm{~mm} \mathrm{ka}^{-1}$ (Table 1) (Ivy-Ochs et al., 2006b). Age uncertainties reflect only analytical errors.

\section{Stratigraphic data}

\subsection{General outline}

Through geological survey into outcrops or in borehole sediments, thin layers of organic bog sediments and some relics of buried palaeosols were found as intercalations in glacigenic deposits. The former are related to warmtemperate climate conditions (interglacial or interstadial: asterisks in Fig. 2). The most distal position reached by the glacier during a particular glacial episode, corresponding to a maximum expansion stadial, is recognized by the most external ice-marginal landform correlated, through facies analysis, with the glacigenic deposits that cover an interglacial marker. The mappable boundary of the upper stratigraphic unit corresponds to the distal edge of this marginal form.

These elements, supplemented by pedostratigraphical and chronological data, distinguish 10 Afs (Gianotti, 2007) related to at least as many glacial episodes (Fig. 2). These glacigenic units lie on bedrock and on each other, with basal and vertical erosional contacts.

The oldest Af, Mongrando (1 in Fig. 2), is referred on paleomagnetic evidence to a glacial episode during the Early Pleistocene (Carraro et al., 1991), while the youngest Ivrea Af (10 in Fig. 2) is referred to the last glacial episode at the end of Late Pleistocene. The other eight AFs are related to glacial episodes of the Middle Pleistocene, with the possibility of a Late Pleistocene age for the Piverone Af.

The Mongrando and Bornasco Afs are separated by the Bosa Palaeosol, the Bornasco and Montino Afs by the Sorgente Sulfurea Unit (interglacial?), the Montino and Zubiena Afs by the Cascina Comunità Paleosol, the 
Parogno and Torrazzo Afs by the Cascina Gianetto Unit (interglacial?) and the Serra and Piverone Afs by the Alice Superiore Unit (interstadial; Fig. 6).

The other stratigraphic boundaries were identified by pedostratigraphy. The various glacigenic units can be assigned to three pedogroups according to the Munsell colours of the soil B horizons and of their colluvial products (Fig. 2): pedogroup A (Mongrando to Zubiena AFs) shows hue 2.5YR, pedogroup B (Parogno and Torrazzo AFs) hue 5YR, and pedogroup C (Magnano to Ivrea AFs) hue 7.5YR. Within the less weathered pedogroup, Magnano Af $(\mathrm{C} 1)$ is distinguishable from the Serra and Piverone AFs (C2) by the greater thickness of soil horizons $(>2 \mathrm{~m})$ and a higher degree of weathering of the clasts. Piverone Af is distinct from Ivrea Af (C3) essentially by a conspicuous difference in the thickness of subsoil weathering in the permeable sand and gravel deposits (5.3.2).

\subsection{Lithofacies and morphology}

Facies analysis also yielded new elements crucial to stratigraphical reconstruction and to interpretation of the landforms (Forno and Gianotti, 2005). The IA largely consists of marginal glacial deposits, especially subaerial and subaqueous gravity flow till. Ice-marginal forms, moraines dominated by flow till and kame terraces of flow till with glaciolacustrine and fluvioglacial sediments, are well expressed and continuous. More than 50 terminal morainic ridges are recognized, each formed by an alignment of moraine ridges and kame terraces. These features were used to reconstruct the various, sometimes complicated, extensions (lobes) of the Dora Baltea glacier margin. In the distal sector, the glacier was subdivided into three main terminal lobes during the Serra and Piverone glacial episodes (Fig. 2). In the right proximal sector, the glacier showed some minor lobes. Both lateral and frontal marginal forms are preserved. In the internal left sector, where the largest and most regular lateral moraines extend (Serra d'Ivrea), the glacial margin must have had a more regular configuration during the Serra and Piverone episodes.

Subglacial deposits are largely buried under the more recent marginal till, and are exposed only locally. They are represented mainly by melt-out till and subordinate lodgment till, usually in close association. Lodgment till is usually not very thick ( $\mathrm{dm}$ to $\mathrm{m}$ ) and, in the proximal sector of the amphitheatre, it rests directly on bedrock. A typical and frequent sequence of only metre thickness, outcropping in stream incisions between moraines, is formed by lodgment till at the base, overlain by sub-glacial melt-out till and lacustrine fine deposits at the top. This sequence records glacial retreat without local stopping of the glacial margin. Subglacial deposits are stratigraphically

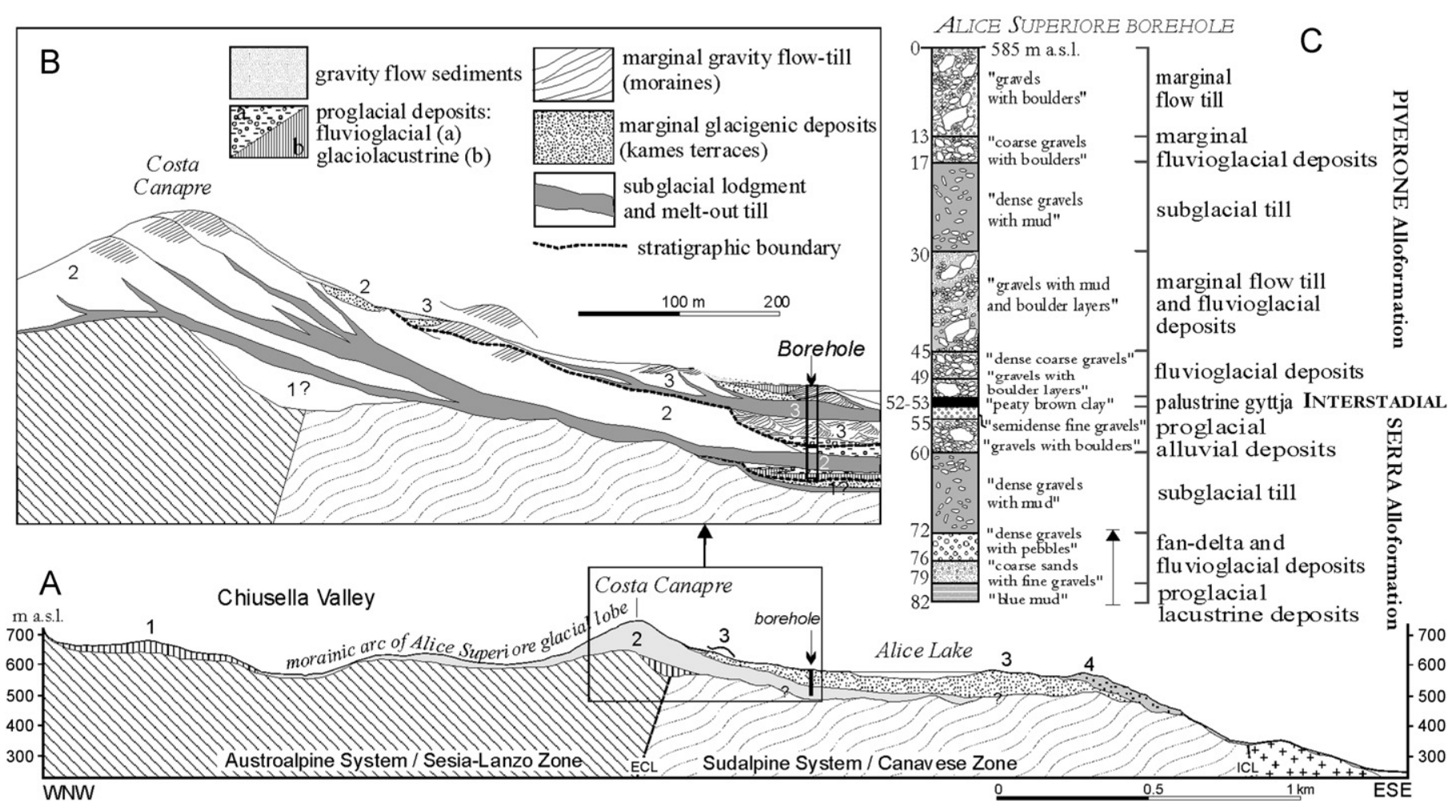

Fig. 6. Geologic cross-section and facies analysis for the stratigraphic distinction between Serra Af and Piverone Af, based on drilling from the Alice Superiore intermorainic basin. (A): Cross-section of the right lateral sector, with stratigraphic subdivisions; legend as in Fig. 5, profile trace is shown in Fig. 4. (B): Detail of section A, with principal patterns of facies association; the two-sub-glacial till layers, encountered during drilling, can be correlated with the outer marginal glacial deposits of Serra Af and Piverone Af. (C): Stratigraphic log of the drilling (modified from Arobba et al., 1997). A peaty layer separates the two-glacigenic sequences, each containing proglacial, sub-glacial and glacial marginal deposits. 
correlated with marginal glacial deposits found in more distal positions.

\subsection{Recent glacial sequence of the $I A$}

The glacigenic deposits with the less weathered soils (pedogroup C) make up a large part of the amphitheatre (Fig. 2). They are almost the only deposits in the frontal and in the right sectors. On the other hand, these deposits form the more regular and longest moraines (Serra d'Ivrea) in the left sector, where also the oldest units are well preserved. A minor morainic arc, developed in a slightly more proximal position, is formed by distinct moraines, such as the Piccola Serra in the left sector (Figs. 3 and 7). Between Serra and Piccola Serra a third morphostratigraphic unit is distinguishable. This Piverone unit is represented by small and discontinuous moraines, with rounded crests, and by numerous kame terraces. The three morphological units could be related to a single glacial episode, on the basis of the same Munsell colour index (hue 7.5YR) values of soils and soil colluvium, and on the basis of similar degrees of erosional modification. However, some stratigraphic elements suggests that this succession is separable into three Afs (Serra, Piverone and Ivrea Afs), each one referable to a different glacial episode.

\subsubsection{Distinction between the Serra and Piverone Afs}

At the outlet of the valley, the right side of the Dora Baltea Glacier was characterized by a sequence of glacial lobes that crossed the local watershed between the Dora Baltea basin and Chiusella Valley (Fig. 6). These lobes developed during various episodes of expansion, but only those of the Serra and Piverone episodes resulted in distinct and preserved morainic arcs. The most important of these lobes (Alice Superiore lobe) is clearly aligned with the two Canavese faults, which channelled and confined glacial erosion into the belt of fractured substratum of the Canavese Zone (Fig. 4).

In 1984 an 82-m-deep borehole for water research was drilled at q. $585 \mathrm{~m}$ in the internal depression of the Alice Superiore morainic lobe, without reaching the substratum.
At a depth of $52 \mathrm{~m}$, a 1-m-thick peaty layer was encountered between two glacigenic sequences. These comprise fluvioglacial, glaciolacustrine deposits and ablation till, each including a diamicton formation, more than $15 \mathrm{~m}$ thick, interpreted as lodgment till. The peaty layer was dated at $>43 \mathrm{kyr}{ }^{14} \mathrm{C} \mathrm{BP}$ and post-Eemian, in agreement with Fagus pollen content. It was considered as a Late Pleistocene interstadial marker, separating the Serra Group deposits from the Bollengo Group ones. The entire Serra Group was assigned to the Late Pleistocene (Arobba et al., 1997).

A different stratigraphic and chronological reconstruction is now proposed, using the data from the Alice Superiore coring (Arobba et al., 1997). Each sub-glacial sedimentary layer can be correlated to one or more alignments of glacial marginal forms located in more distal positions (Fig. 6).

The lower sub-glacial formation can be correlated with two principal moraines of the Alice Superiore lobe, forming a morainic arc extended in Chiusella Valley up to the local edge of amphitheatre $3 \mathrm{~km}$ distant from the coring site. Its main right lateral moraine (Costa Canapre moraine, reaching an elevation of $750 \mathrm{~m}$ ) corresponds, on morphologic grounds, to the Serra d'Ivrea moraine on the opposite side of the amphitheatre (Fig. 5). These moraines are related to the Serra Af.

The upper sub-glacial formation is correlated with the more proximal and lower marginal forms, represented by two morainic arcs with kame terraces extending $800 \mathrm{~m}$ from the borehole site and $100 \mathrm{~m}$ lower than the Costa Canapre moraine. These elements are part of the Piverone Af, related to a glacial episode that followed the Serra glacial episode. On the opposite (left) sector of the amphitheatre, this unit is represented by low and short moraines and kames, located between the higher moraines of the Serra d'Ivrea (Serra Af) and the Piccola Serra (Ivrea Af; last glacial episode).

A palaeosol (Rio Rudo Paleosol), embedded in two sequences of glaciolacustrine deposits, crops out in a similar stratigraphic position $8 \mathrm{~km}$ southward. The palaeosol separates the Serra and Piverone Afs and provides further support for the reconstruction.

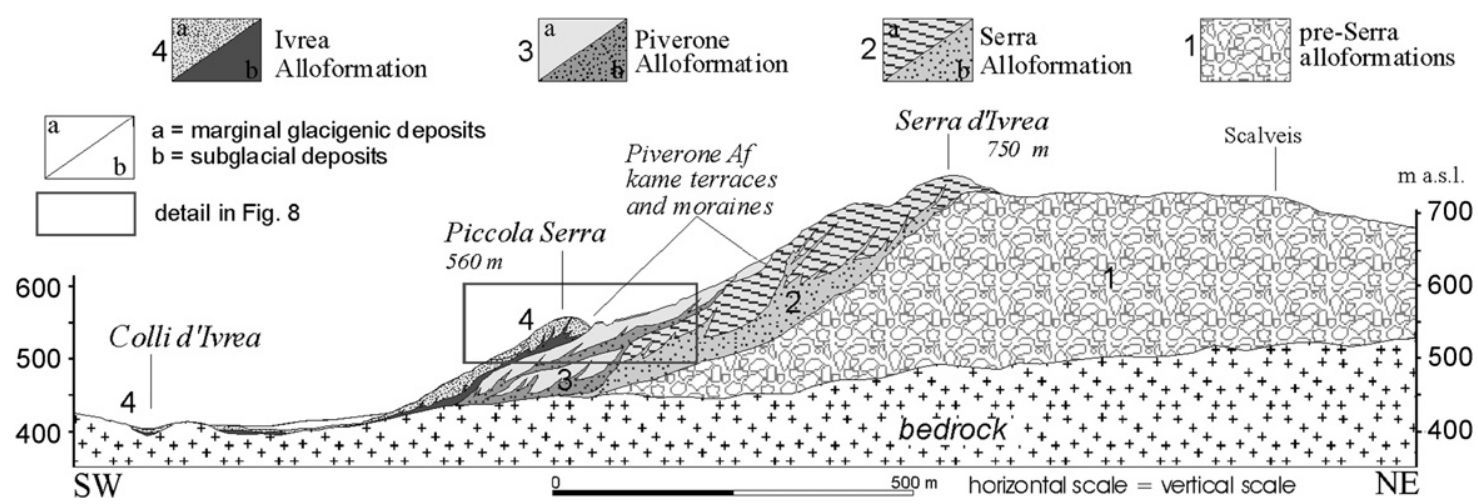

Fig. 7. Geologic cross-section of the internal part of the left lateral sector, NE of Chiaverano. Profile trace is shown in Fig. 4. Detail in Fig. 8. 


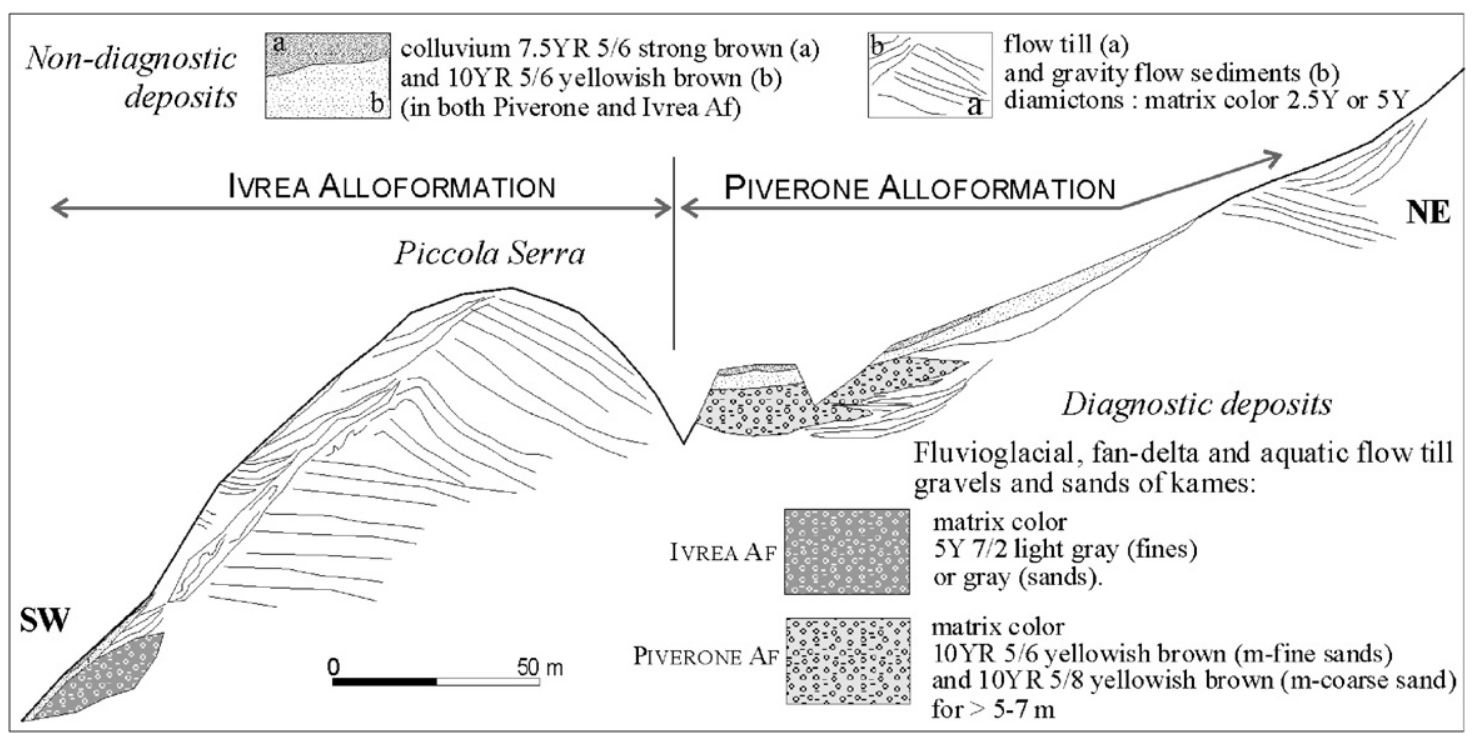

Fig. 8. Geological profile (detail in Fig. 7) for the pedostratigraphical distinction between Piverone Af and Ivrea Af, based on characteristics of soil substratum (C horizon) developed on marginal fluvioglacial deposits of kame terraces.

\subsubsection{Distinction between Piverone and Ivrea Afs (penultimate and last glacial episodes)}

Soils developed on marginal glacigenic deposits of slightly different ages are very difficult to compare, because of the strong activity of gradational processes. Soils are relatively rare and always show a B horizon of decimetric thickness cut-off to various degrees. Moreover, their evolution is strongly controlled by the texture of deposits and permeability. Soil-derived colluvium is much more frequent: it often displays a typical double layer, $1-2 \mathrm{~m}$ thick, formed by reddish structureless silty sand 7.5YR 5/6 overlaying a yellowish sand 10YR 5/6 (Fig. 8). However, there are discernible differences in the degree and depth of weathering of the soil substratum (C horizon) into permeable kame deposits of different ages (Fig. 8), particularly the sand matrix of fan-delta fluvioglacial deposits, constituted of stratified sand and gravel, deposited in marginal lakes and forming kame terraces on the proximal side of moraines.

The kame deposits of the more distal units (Serra and Piverone Afs) show no sign of pedogenesis below more than $2 \mathrm{~m}$ depth, with the exception of a marked colouration of the matrix. It appears weakly altered for at least $6-7 \mathrm{~m}$ as it exhibits a yellow colour (10YR 5/6 for medium-fine sand; $10 \mathrm{YR} 5 / 8$ for medium-coarse sand). With the prevalence of layers of diamictons derived from flow processes, formed by finer sediments, the colour of the silty sand matrix is pale yellow-grey $(2.5 \mathrm{Y}$ or $5 \mathrm{Y})$. The colour of the matrix is associated with the texture of single layers, with typical alternations of yellow-grey $2.5 \mathrm{Y}$ for silty sand layers, 10YR for medium sand ones, and grey (nearly unweathered) for coarse sand and gravel. Therefore, this weathering is due to hydrolysis probably driven also by water table activity, and it is influenced by the specific surfaces of the grains and permeability.
In kames of the more proximal unit (Ivrea Af), the fluvioglacial gravels and sands, and the aquatic flow till diamicton exhibit a matrix colour 5 Y 7/2 (fines) or grey (sand) at $1-2 \mathrm{~m}$ depth. This suggests a markedly more recent age for this unit. These differences in the alteration of the marginal kame deposits are particularly well exposed in the left lateral sector, near Chiaverano, where a gorge cuts the Piccola Serra moraine and carves into the proximal side of the Serra of Ivrea (Figs. 7 and 8).

\subsubsection{The sequence of glacial retreat during the last glaciation (Ivrea $A f$ )}

The recognition of alignment of typical ice-marginal landforms (moraines and kame terraces) has allowed recognition of 12 principal stadials of the LGM and Lateglacial, of which six stadials are in the amphitheatre (Fig. 4) and six stadials are in the Dora Baltea Valley (Fig. 1). It also allows reconstruction of the history of glacial retreat from the amphitheatre to the cirques. The Ivrea $\mathrm{AF}$ can be subdivided in 12 allomembers of glacigenic deposits.

The maximum expansion stadial is represented by a discontinuous morainic arc, named the Andrate Allomember, constituted by two lateral moraines (Piccola Serra on the left and Parella moraine on the right) and a frontal moraine at Strambino, which are located $110 \mathrm{~km}$ from the present day Monte Bianco glaciers. A first glacial stadial, where the glacier halted only for a limited time, is represented by an alignment of kame terraces (Quintas Allomember) found on the internal side of the main morainic arc.

The other records of glacial retreat (Pavone, Bienca, Prà San Pietro and Germano allomembers) are represented by small and discontinuous moraines exposed on the Colli d'Ivrea hills. In the internal plain, glacial deposits are 
buried below lacustrine and alluvial sediments. Consequently, the complete reconstructon of the ice margin is highly speculative here (Fig. 4).

After the Quintas Stadial, rapid downwasting of a clean Dora Baltea glacier (very little surface or entrained debris) is suggested by wide areas of granulitic roches moutonnées without till cover in the distal sector of Colli d'Ivrea between Pavone and Chiaverano. Only to the SW of Ivrea, at a location $100 \mathrm{~km}$ from Monte Bianco Little Ice Age fronts, is there a notable frontal moraine, $600 \mathrm{~m}$ long and 4-5 $\mathrm{m}$ high, which reflects a brief glacier readvance. Along with two other lateral moraines, it defines the terminal morainic arc of Pavone Am.

During the Bienca Stadial, a glacial lobe persisted on the left side of Dora Baltea glacier in a large depression of the northern sector of Colli d'Ivrea, where some concentric moraines and kames are found (Forno et al., 2005a, b). An ice-damned lake formed in the Bienca hollow as the glacier retreated (Prà San Pietro Am). Similar sequences of moraines, marginal kame terraces and lower lacustrine terraces recur in various depressions between the hills at different heights, with the last one in the more proximal Lago Nero hollow (Germano Am). By the Germano Stadial, the Dora Baltea Glacier had definitively left the IA.

The elements that allow recognition of the successive halts of the glacier during the retreat phase into the Dora Baltea Valley are (Fig. 1): a frontal moraine in Torredaniele, $82 \mathrm{~km}$ from Monte Bianco (Torredaniele $\mathrm{Am})$; a concentration of granitic erratic blocks in the valley floor near Bard (Bard Am; Carraro, 1992); alignments of kame terraces, $18 \mathrm{~km}$ long on the left side of valley between Roisan and Chambave, connected with lateral-frontal relics of moraines $58 \mathrm{~km}$ from Monte Bianco (Chambave $\mathrm{Am}$, only in part equivalent to the Chambave stade of Novarese, 1915); a frontal arc dissected by the Dora Baltea River near Saint Pierre, $26 \mathrm{~km}$ from Monte Bianco (Saint Pierre Am); a group of lateral moraines on the right of valley floor at La Villette and Dolonne near Courmayeur, at only $3 \mathrm{~km}$ from actual Brenva Glacier front (Courmayeur Am; Porter and Orombelli, 1982), and a terminal moraine in the Ferret Valley (Planpincieux Am; Porter and Orombelli, 1982).

\section{Chronological attribution based on biostratigraphy}

A precise chronological attribution of the interstadial/ interglacial marker of the Alice Superiore sequence is the basis for correlation of Serra and Piverone Afs to the MIS stratigraphy. The Alice spectrum was derived from a unique sample from a peaty clayey layer, with good preservation and high pollen concentrations $\left(>111,000 \mathrm{~g}^{-1}\right)$. It indicates a moist and temperate forested environment (A.P. index $88.5 \%$ ), characterized by the dominance of Quercus (25\%), Alnus (17\%), Fagus (13\%) and Betula $(6.2 \%)$ with smaller amounts of Picea $(2.9 \%)$, Carpinus (2.5\%), Abies (4.5\%), Tilia t. cordata (1.7\%),
Ulmus $(0.57 \%)$, Cupressaceae $(0.57 \%)$ and Salix $(0.29 \%)$. Herbaceus taxa $(11.5 \%)$ are represented by Poaceae $(1.41 \%)$, Artemisia $(1.70 \%)$, Ranuncolaceae (1.41\%), Filicales monolete $(1.13 \%)$, Sagittaria $(0.85 \%)$, Potamogeton $(1.41 \%)$ and others (Arobba et al., 1997).

The most complete and continuous pollen sequence suitable for the Middle-Late Pleistocene of Northern Italy is the Azzano Decimo sequence from the Friuli alluvial plain (NE Italy), a study presently in progress. Two possibilities are most probable for the age of the Alice Superiore layer, from comparison of the Alice palynological association and the Azzano Decimo stratigraphy: a MIS 7c age or a MIS 5c age. During MIS 7a-b-c, the Azzano profile shows long phases with Fagus-Abies dominance. The Alice spectrum is particularly similar to Azzano in MIS 7c, with Fagus-Abies-Quercus associations. The first part of the Azzano Eemian is characterized by the absence of both Fagus and Abies. The second part of Eemian shows Abies and Carpinus with subordinate Fagus. During MIS 5c, a short phase is noted that is similar to the Alice spectrum, unless the presence of Betula in the Alice sediments is due to the different environment and altitude. After MIS 5a, Quercus no longer dominates and forest associations as dense as those found at Alice are missing after the Dürnten phase (60 ka BP) (C. Ravazzi, personal communication).

An attribution of the Alice marker to MIS 5c would support the correlation of Serra Af with the MIS 6 glacial episode and of Piverone Af to the MIS 4 glacial episode. Otherwise, Serra Af must be correlated to an even older stage (MIS 8?) and Piverone Af to MIS 6, if the Alice marker were related to MIS 7c (Fig. 9).

\section{Chronological data based on surface exposure dating with cosmogenic ${ }^{10} \mathrm{Be}$}

The analysed rock samples are discussed in order of the stratigraphic position of their location (Figs. 4 and 9). ${ }^{10} \mathrm{Be}$ exposure ages are listed in Table 1. Ivrea 7 (Broglina) is from the largest erratic block found on the highest crest of the Serra d'Ivrea moraine complex. Although the boulder is large, its dimensions have only been recently exposed due to road construction on the moraine crest. How far under sediment it lay since its deposition is difficult to gauge. Similarly, Ivrea 8 is a somewhat smaller boulder near the moraine crest road. As it is likely that the boulders were recently fully uncovered due to human activity, the ages of $27.9 \pm 3.1$ and $32.4 \pm 4.0 \mathrm{ka}$ give only a minimum age for construction of the Serra d'Ivrea moraine. The remaining boulder and bedrock surfaces are all related to the last glaciation and later. Ivrea 6 is a granite erratic block that supplied the oldest age for last glacial deglaciation in the IA $(20.8 \pm 1.5 \mathrm{ka})$. This age may record deposition at the Dora Baltea Glacier margin, while its front was withdrawing from Pavone Stadial to the subsequent Bienca Stadial position. Ivrea 1 is a similar granite erratic block, whose position is just slightly more proximal than the Prà 


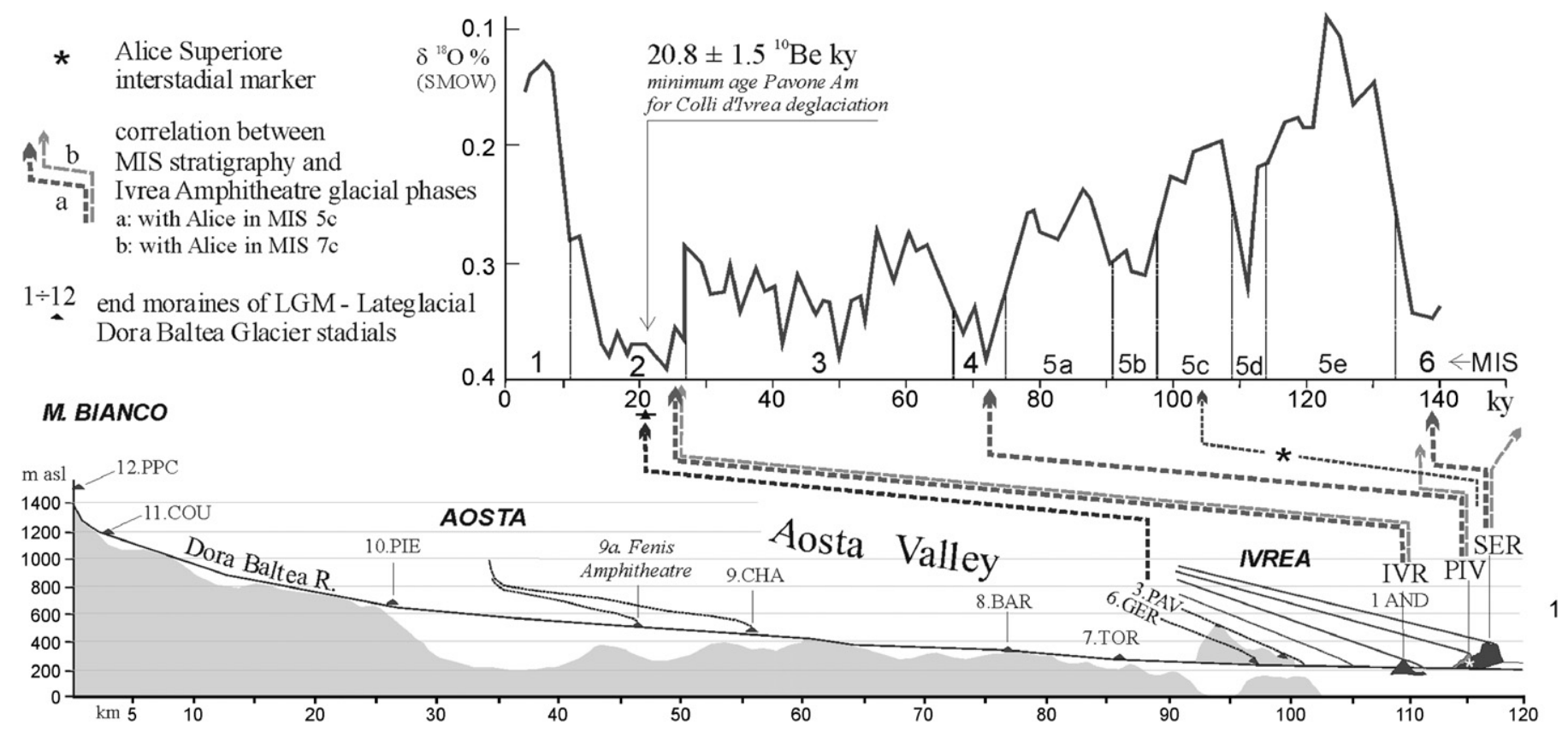

Fig. 9. Correlations between the allostratigraphic units of the Morainic Amphiteatre of Ivrea related to the last three glacial episodes (Serra, Piverone and Ivrea alloformations) and the global palaeoclimate record, here represented by the Last Interglacial-Glacial Cycle MIS stratigraphy, based on $\delta^{18} \mathrm{O}$ in Globigerina bulloides from a Tyrrhenian Sea core. Depending on the chronological position of the Alice Superiore interstadial marker, two hypotheses are proposed for the Piverone Alloformation. LGM-Lateglacial stadials moraines are plotted on a longitudinal profile of the Dora Baltea Valley and of the amphitheatre, showing the buried valley floor conformation. The ${ }^{10} \mathrm{Be}$ exposure age from Ivrea $6(20.8 \pm 1.5)$, which we believe gives the best age for onset of withdrawal of the Dora Baltea Glacier from the amphitheatre during the Pavone Stadial, is shown.

San Pietro Stadial position. The exposure age of this block is $17.4 \pm 2.6 \mathrm{ka}$, and may relate to a phase of glacial retreat between the Prà San Pietro Stadial and the Germano Stadial positions. The granite boulder Ivrea 3 (Lago Nero) is located on the top of a roche moutonnée, not far from the Ivrea 1 sample site and in similar stratigraphic position. Neverthless, it has a much younger exposure age $(13.1 \pm 1.0 \mathrm{ka})$. Finally, Ivrea 10 and 11 come from the distinctive roche moutonnée of the lower Dora Baltea floor valley, near Donnas village. The ages $(14.6 \pm 1.2$ and $14.0 \pm 0.9 \mathrm{ka}$ ) provide a minimum age for the glacial retreat between Torredaniele Stadial and Bard Stadial positions (Figs. 1 and 9).

\section{Discussion}

The three most recent morphologic units of the IA (corresponding to pedounits $\mathrm{C} 2$ and $\mathrm{C} 3$ ) considered here may be related to a single glacial episode, on the basis of similar characteristics of weathering and morphology. In that case the Serra Af could represent the maximum expansion of the last glaciation and the internal sequence would be the product of halts or readvances during the glacial retreat phase. Otherwise, the Piverone Af has to be correlated to either a stade of retreat of a penultimate episode, or it has to be considered as the maximum expansion stade of the last glacial episode. In this third case, Piverone Af and Ivrea Af could form a complex similar to the Maximalständ and Hochständ of LGM end moraines observed in the Austrian Alps by van Husen (1997) and to the twofold LGM glacial advance in the Tagliamento amphiteatre (Monegato et al., 2007).

New evidence suggests that this succession, corresponding to the more recent part of Serra Group and to the Bollengo-Albiano Group of Carraro (1992), is separable into three units (Serra, Piverone and Ivrea Afs) each connected with a different glacial episode. The Serra d'Ivrea moraines are most likely related to the last glacial episode of the Middle Pleistocene (MIS 6) on the basis of the following evidence: (i) the presence of a further morphostratigraphic unit (Piverone Af moraines), interposed between the Serra and Bollengo-Albiano groups throughout the entire amphitheatre; (ii) the Piverone Af can be distinguished from the Serra Group, based on analysis of stratigraphic relationships in the Alice Superiore section (Fig. 6); (iii) the peaty level separating Serra and Piverone AFs can be referred to MIS 5c (or MIS 7c), according to palynological correlation; (iv) the Piverone Af can be distinguished from the Bollengo Group (Ivrea Af) on the basis of significant differences in $\mathrm{C}$ horizon weathering profile thickness and (v) therefore only the Ivrea Af is referred to the last glacial episode (MIS 2).

A few lines of evidence support the hypothesis that Serra Af must have formed during the glacial episode correlated to MIS 6, and Piverone Af to MIS 4. The biostratigraphic correlation of Alice Superiore interstadial peaty layer, interbedded between the Serra and Piverone AFs, with the MIS 5c layer of Azzano Decimo sequence (NE Italy) does 
not seem to be preferable to the alternative correlation with the Azzano MIS 7c level. New investigations are clearly needed. The younger age would instead be in agreement with the low degree of weathering of the Serra deposits. Moreover, the wide extent of the Serra Af glacigenic deposits, which constitute the majority of the amphitheatre, seems to be better referred to an important glacial expansion as globally indicated by MIS 6 .

In such a case the importance of the MIS 4 glacial episode would be attested. In the IA, it would have reached a greater extent than during the last expansion episode, but significantly lower than the extent reached in the preceding glacial episode, the last of the Middle Pleistocene (Fig. 2). Piverone Af would be referred to the local LGM, different from the global LGM (during MIS 2), as it would correspond to the maximal glacial expansion for Dora Baltea basin within the Last Interglacial-Glacial Cicle (from MIS 5 to MIS 2). This result seems in contrast with the general evidence for the European LGM (see Ehlers and Gibbard, 2004) and merits further study.

Before the present work, the only dates constraining the last glacial retreat succession of Dora Baltea Glacier were the $14,200 \pm 150{ }^{14} \mathrm{C}$ BP value from gyttja of Alice Superiore peat (Schneider, 1978), supplying a minimum age for deglaciation in the IA, and the $9070 \pm 120{ }^{14} \mathrm{C}$ BP $(10,272-9955$ cal BP) age obtained from peat exhumed at the front of Rutor Glacier at $2510 \mathrm{~m}$ asl in the Aosta Valley (Orombelli, 1998), related to the phase of maximum glacier retreat. The present dating with cosmogenic ${ }^{10} \mathrm{Be}$ from boulder Ivrea $6(22.3-19.3 \mathrm{ka})$ supplies the oldest age for last glacial deglaciation in the IA. This indicates clearly that the Dora Baltea Glacier formed the Ivrea Af during the global LGM in MIS 2. The exposure age of Ivrea 1 (which spans $20.0-14.8 \mathrm{ka}$ ) is slightly younger than the age for Ivrea 6 , but indistinguishable within error ranges. The latter is nevertheless located in a slightly more distal position. The age of Ivrea 6 is in excellent agreement with the exposure ages from erratics from the outermost LGM moraines at Wangen (Solothurn, Switzerland) on the northern Swiss Alpine foreland. The data from Wangen indicate that the initial moraine abandonment was underway by $22.1-19.5 \mathrm{ka}$ based on ${ }^{10} \mathrm{Be}$ (Ivy-Ochs et al., 2006b). Good correlation can be found also with the Remanzacco subsynthem recessional moraines in the Tagliamento Amphiteatre in eastern Italian Alps, dated between 21 and $18.8 \mathrm{cal} \mathrm{ka}{ }^{14} \mathrm{C}$ (Monegato et al., 2007).

The exposure age (13.7-11.9 ka) from granite erratic Ivrea 3 is certainly much younger than the timing of local deglaciation. Ivrea 3 is located in a similar position to Ivrea 1 with respect to the glacial margin of Prà San Pietro Stadial. There is no evidence for till cover of this boulder, which rests directly on glacially abraded bedrock. This obtained, presumed low age is more likely related to surface erosion or spalling of the boulder. As well, the Ivrea 10 and 11 exposure ages (15.8-13.24 ka) of Donnas roche moutonneé are also considered as somewhat too young. Ages of 15-16 ka for Lateglacial stadial deposits
(Gschnitz Stadial) which are located in the main Alpine valleys at distances less than some dozens of kilometres from actual glaciers have been determined. At the type locality of the Gschnitz stade at Trins (Gschnitz Valley, Austria) ${ }^{10} \mathrm{Be}$ exposure dating of boulders shows that this moraine stabilised no later than $15.4 \pm 1.4 \mathrm{ka}$ (Ivy-Ochs et al., 2006a). In contrast, the Donnas site (Ivrea 10 and 11) is located $80 \mathrm{~km}$ from Monte Bianco glaciers and is not at the outlet of an important tributary valley. The Donnas site would have therefore been ice free several 1000 years earlier than the age indicated by ${ }^{10} \mathrm{Be}$. As the rock surface is nicely polished, it may have been covered by sediment and/or soil and protected during part of the exposure period leading to the anomalously young age.

\section{Conclusions}

A new geological survey in the IA has increased knowledge of morphologic, sedimentologic, stratigraphic, and chronologic features of this important piedmont landscape. Facies analysis and morphological reconstruction of the Dora Baltea Glacier margin evolution allow further subdivision of the previously defined three allostratigraphic groups. Ten Afs were mapped and attributed to main glacial episodes, deposited from the end of the Early Pleistocene to the Late Pleistocene. Detailed palynologic analysis will be necessary to characterize the identified organic levels which are used here as stratigraphic markers (interglacial, interstadial or stadial) and possibly to date them by correlation to well-known biostratigraphical sequences.

Three glacial units (Serra Af, Piverone Af and Ivrea Af) are distinguished between the more recent and less weathered (pedogroup C) deposits. The Serra Af, Piverone Af and Ivrea Af can be tentatively correlated to MIS 6, MIS 4 and MIS 2, respectively, on biostratigraphical and pedostratigraphic bases. The obtained ${ }^{10} \mathrm{Be}$ ages (LGM) for boulders Ivrea 7 and 8 from the Serra of Ivrea moraine are in contradiction with the biostratigraphic data, so the question of the age of Serra d'Ivrea is still unresolved.

More detailed data have been obtained about the last glacial retreat phase: the more recent Af (Ivrea Af) was resolved into 12 principal allomembers referable to glacial stadials of LGM-Lateglacial - 6 stadials in amphitheatre and 6 stadials in Dora Baltea Valley. The exposure ages of $20.8 \pm 1.5$ and $17.4 \pm 2.6 \mathrm{ka}$ from two erratic boulders (Ivrea 6, Ivrea 1) provide clear evidence for formation of the Ivrea Af during the last global glacial maximum.

\section{Acknowledgements}

We are grateful to the Zurich AMS facility staff for the analysis of our samples. The Zurich AMS facility is jointly operated by the Swiss Federal Institute of Technology, Zurich, and by Paul Scherrer Institute, Villigen, Switzerland. We thank C. Ravazzi for his ready notice about the correlation between Alice Superiore pollen spectrum and 
the biostratigraphic sequence of Azzano Decimo. We especially thank the two anonymous reviewers for their numerous helpful suggestions.

\section{References}

Arobba, D., Calderoni, G., Caramiello, R., Carraro, F., Giardino, M., Quagliolo, P., 1997. Palynological and radiometric evidence of a last glacial-interstadial from peat sediments in the Ivrea morainic amphitheatre (NW-Italy). Geologia Insubrica 2 (2), 143-148.

Baretti, M., 1877. Studi geologici sul gruppo del Gran Paradiso. Atti della Reale Accademia Nazionale dei Lincei 3 (1), 122 (Roma).

Biino, G., Compagnoni, R., 1989. The Canavese Zone between the Serra d'Ivrea and the Dora Baltea River (Western alps). Eclogae Geologicae Helvetiae 82, 413-427.

Bini, A., 1997. Problems and methodologies in the study of the Quaternary deposits of the southern side of the Alps. Geologia Insubrica 2 (2), 11-20.

Bortolami, G., Carraro, F., Friz, C., Govi, M., Sacchi, R., 1966. Foglio 43 Biella della Carta Geologica d'Italia alla scala 1:100,000, second ed. Servizio Geologico Italiano, Roma.

Brugiapaglia, E., 2001. Le lac de Villa : un site clé pour l'histoire de la végétation terdiglaciaire et holocène en Vallée d'Aoste (Italie). Revue Valdôtaine d'Histoire Naturelle 55, 55-72.

Bruno, L., 1877. I terreni costituenti l'anfiteatro allo sbocco della Dora Baltea, Tipografia F.L. Curbis, Ivrea, pp. 65.

Carraro, F., 1992. La zona pedemontana da Ivrea ad Arona. Depositi quaternari. In: Dal Piaz, G.V. (Ed.), Le Alpi dal Monte Bianco al Lago Maggiore, Società Geologica Italiana, vol. 3(a). Guide Geologiche Regionali, BEMA, Milano, pp. 186-209.

Carraro, F., Petrucci, F., 1969. Carte Géologique de la Plaine du Piémont 1: 400,000. VIII Congrés INQUA, Paris.

Carraro, F., Medioli, F., Petrucci, F., 1975. Geomorphological study of the Morainic Amphitheatre of Ivrea, Northwest Italy. Bulletin, 13. Royal Society of New Zealand, Wellington.

Carraro, F., Lanza, R., Perotto, A., Zanella, E., 1991. L'evoluzione morfologica del Biellese occidentale durante il Pleistocene inferiore e medio, in relazione all'inizio della costruzione dell'Anfiteatro Morenico d'Ivrea. Bollettino del Museo Regionale di Scienze Naturali Torino 9 (1), 99-117.

Cremaschi, M., 1987. Paleosols and vetusols in the central Po plain (Northern Italy). Unicopli, Milano, pp. 306.

Dunne, J., Elmore, D., Muzikar, P., 1999. Scaling factors for the rates of production of cosmogenic nuclides for geometric shielding and attenuation at depth on sloped surfaces. Geomorphology 27, 3-11.

Ehlers, J., Gibbard, P.L. (Eds.), 2004. Quaternary Glaciations: Extents and Chronology, Part I: Europe. Elsevier, pp. 440.

Forno, M.G., Gianotti, F., 2005. Arret 1. Serra d'Ivrea et Petite Serra (Andrate). Arret 2. Stratigraphie de la Serre d'Ivrea (Chiaverano). In: Deline, P., Giardino, M., Nicoud, G. (Eds.), Le Quaternaire des vallées alpines. Collection Edytem-Cahiers de Géographie, vol. 3. Association Française pour l'Etude du Quaternaire, pp. 137-143.

Forno, M.G., Gianotti, F., Grosso, F., 2005a. Il modellamento glaciale dei colli dioritici di Ivrea. In: Convegno Nazionale A.I.Geo. Montagne e Pianure, Padova, 15-17 febbraio 2005, abstract, 99-101.

Forno, M.G., Gianotti, F., Grosso, F., 2005b. Arret 3. Les Collines d'Ivrea. Affleurements rocheux à modelé glaciaire à l'intérieur de l'AMI (Biò, Borgofranco d'Ivrea). In: Deline, P., Giardino, M., Nicoud, G. (Eds.), Le Quaternaire des vallées alpines. Collection Edytem-Cahiers de Géographie, vol. 3. Association Française pour l'Etude du Quaternaire, pp. 144-146.

Franchi, S., Stella, A., 1933. Foglio 43 Biella della Carta Geologica d'Italia alla scala 1:100,000, first ed. Real Ufficio Geologico Italiano, Roma.

Franchi, S., Mattirolo, S., Novarese, V., Stella, A., 1912. Foglio 42 Ivrea della Carta Geologica d'Italia alla scala 1:100,000, first ed. Real Ufficio Geologico Italiano, Roma.
Gianotti, F., 2007. Stratigrafia dell'Anfiteatro morenico di Ivrea. Ph.D. Thesis, unpublished, Università degli Studi di Torino, pp. 254.

Goldthwait, R.P., Matsch, C.L., 1988. Genetic Classification of Glacigenic Deposits. Balkema, Rotterdam, pp. 294.

Ivy-Ochs, S., 1996. The dating of rock surfaces using in situ produced $10 \mathrm{Be}, 26 \mathrm{Al}$ and $36 \mathrm{Cl}$, with examples from Antarctica and the Swiss Alps, Ph.D. Thesis, ETH-Zürich, No. 11763, pp. 196.

Ivy-Ochs, S., Kerschner, H., Kubik, P.W., Schlüchter, C., $2006 \mathrm{a}$. Glacier response in the European Alps to Heinrich event 1 cooling: the gschnitz stadial. Journal of Quaternary Science 21 (2), $115-130$.

Ivy-Ochs, S., Kerschner, H., Reuther, A., Maisch, M., Sailer, R., Schaefer, J., Kubik, P.W., Synal, H.-A., Schlüchter, C., 2006b. The timing of glacier advances in the northern European Alps based on surface exposure dating with cosmogenic $10 \mathrm{Be}, 26 \mathrm{Al}, 36 \mathrm{Cl}$, and $21 \mathrm{Ne}$. Geological Society of America Special Paper 415, 43-60.

Kohl, C.P., Nishiizumi, K., 1992. Chemical isolation of quartz for measurement of in situ produced cosmogenic nuclides. Geochimica et Cosmochimica Acta 56, 3583-3587.

Martins, C., Gastaldi, B., 1850. Essai sur les terrains superficiels de la vallée du Pô, aux environs de Turin, comparés a ceux de la plaine suisse. Bulletin de la Société Géologique de France Ser. 2 7, 554-605.

Monegato, G., Ravazzi, C., Donegana, M., Pini, R., Calderoni, G., Wick, L., 2007. Evidence of a two-fold glacial advance during the last glacial maximum in the Tagliamento end moraine system (eastern Alps). Quaternary Research 68, 284-302.

North American Commission on Stratigraphy Nomenclature, 1983. North American Stratigraphic Code. American Association of Petroleum Geologists Bulletin 67 (5), 841-875.

Novarese, V., 1915. Il quaternario in Valle d'Aosta e nelle valli del Canavese. Parte III: gli stadi postwurmiani. Bollettino Real Comitato Geologico Italiano, 45 (3-4), 137-194.

Ochs, M., Ivy-Ochs, S., 1997. The chemical behavior of Be, Al, Fe, Ca and $\mathrm{Mg}$ during AMS target preparation modeled with chemical speciation calculations. Nuclear Instruments and Methods in Physics Research B 123, 235-240.

Orombelli, G., 1998. Le torbe del Rutor: una successione significativa per la storia olocenica dei ghiacciai e del clima nelle Alpi. In: Ghelardoni, P. (Ed.), Studi in onore di Mario Pinna. I-Il clima e la storia del clima, 55. Memorie Società Geografica Italiana, pp. 153-165.

Penck, A., Brückner, E., 1909. Die Alpen Im Eiszeitalter, Vol. 3. Christian-Herman Tauchnitz, Leipzig, 761-768.

Penck, A., Brückner, E., du Pasquier, A., 1894. Le Système glaciaire des Alpes. Guide Congress Géologique Internationale. Zurich, Bulletin de la Societe des Sciences naturelles de Neuchatel 22, p. 86.

Porter, S.C., Orombelli, G., 1982. Late-glacial ice advances in the western Italian Alps. Boreas 11, 125-140, Oslo

Sacco, F., 1888. I terreni terziari e quaternari del Biellese. Guadagnini \& Candellero, Torino, pp. 16.

Sacco, F., 1927. Il glacialismo nella Valle d'Aosta. Luigi Checchini, Torino.

Schneider, R.E., 1978. Pollenanalytische Untersuchungen zur Kenntnis der Spät-und postglazialen Vegetationsgeschichte am Südrand der Alpen zwischen Turin und Varese (Italien). Botanische Jahrbuch Systematische 100 (1), 26-109.

Stone, J.O., 2000. Air pressure and cosmogenic isotope production. Journal of Geophysical Research Solid Earth 105 (B10), 23753-23759.

Studer, B., 1844. Lehrbuch der physikalischen Geographie und Geologie, vol. 1. Chur und Leipzig, Bern.

Synal, H.A., Bonani, G., Döbeli, M., Ender, R.M., Gartenmann, P., Kubik, P.W., Schnabel, C., Suter, M., 1997. Status report of the PSI/ETH AMS facility. Nuclear Instruments and Methods in Physics Research B 123, 62-68.

van Husen, D., 1997. LGM and late-glacial fluctuations in the eastern Alps. Quaternary International 38/39, 109-118. 